\title{
ANALISIS PENGENDALIAN KUALITAS PRODUK BIJI PLASTIK UD. LESTARI
}

\author{
Nurotul Sofi Anisyaful Laila \\ Department of Management FEB UMM \\ E-mail: shofylyla@gmail.com
}

\begin{abstract}
The aim of this study was to examine the problems and solutions to quality control of pellets at UD Lestari. The data were collected by using observation, documentation, and interview. Then, the data were analyzed by using cause-effect and pareto diagrams. Cause-effect diagram used to found the caused of damage and eliminate it and pareto diagram used to determine and to sort the total of damage from the largest to smallest. The results of the study showed that there were three kinds of problems, such as: different type of pellets, attached pellets to one another, and pellets chunk due to labor, raw material, machine, and method factors. The pareto diagram shows that the shaped plastic seed was a product damage most widely. The most dominant problem faced by UD Lestari was chunk pellets. Thus, the company should monitor labor, raw material, machine, and method used in processing the pellets.
\end{abstract}

Keywords: cause-effect diagram, pareto diagram, quality control

\section{PENDAHULUAN}

Semakin ketat persaingan dunia industri menjadikan perusahaan harus mempertahankan

konsistensinya dalam memenuhi permintaan konsumen dan meningkatkan kualitas produk atau jasa yang dihasilkan. Dunia industri menuntut perusahaan untuk terus berusaha mencari cara dan melakukan upaya agar memiliki kemampuan bersaing yang lebih tinggi daripada perusahaan lain yang bergerak pada bidang yang sama.

Menurut Heizer \& Render (2015) di dalam manajemen operasional terdapat 10 keputusan operasional yaitu: pemilihan dan desain produk, mengelola kualitas, perancangan proses dan kapasitas, strategi lokasi, strategi tata letak, perancangan SDM dan pekerjaan, manajemen rantai pasokan, persediaan, perencanaan kebutuhan dan just in time, penjadwalan jangka pendek dan menengah serta pemeliharaan. Menjaga kualitas produk atau jasa menjadi faktor penting untuk memenangkan persaingan dalam dunia industri.

Garvin dan Davis (1994) menjelaskan bahwa kualitas sebagai suatu kondisi dinamis yang berhubungan dengan produk, manusia atau tenaga kerja, suatu proses dan tugas, serta lingkungan yang memenuhi harapan pelanggan atau konsumen. Dapat disimpulkan bahwa kelangsungan hidup suatu perusahaan sangat tergantung dari 
seberapa besar kemampuan perusahaan dalam memberikan respon terhadap berbagai perubahan.

Pengendalian kualitas perlu dilakukan untuk mencapai tujuan perusahaan. Pengendalian sendiri diartikan sebagai proses untuk memastikan bahwa segala sesuatu yang dilakukan sesuai dengan rencana yang telah ditetapkan, instruksi yang diberikan dan prinsip yang telah ditentukan.

Masyarakat Indonesia dewasa ini sering menggunakan perabotan rumah tangga yang terbuat dari plastik, seperti mangkok, piring, gelas, gantungan baju dan lain sebagainya. Kebutuhan akan bahan baku utama pembuat perabotan rumah tangga plastikpun juga meningkat. UD Lestari merupakan sebuah usaha dagang yang bergerak di bidang pengolahan biji plastik yang berbahan baku kantong plastik (woven stripping) dan plastik sablon (plastik bungkus mie, deterjen, makanan ringan, kopi instan, dan lain sebagainya).
Produk yang dihasilkan UD Lestari ada tiga jenis yaitu biji plastik, tali rafia dan tali rumpon dengan bahan baku yang sama yaitu limbah plastik. Produk biji plastik merupakan produk yang dihasilkan UD Lestari dalam jumlah yang paling besar jika dibandingkan dengan produk lainnya karena selain untuk memenuhi permintaan pasar, biji plastik juga digunakan untuk bahan baku tali rafia dan tali rumpon yang diproduksi sendiri oleh UD Lestari.

Pada perusahaan pengolahan plastik UD Lestari terdapat beberapa kesalahan yang terkadang mengganggu jalannya proses produksi. Kecacatan atau kerusakan produk akan berdampak pada poses produksi UD Lestari secara keseluruhan. Hal ini termasuk dalam hal pemborosan karena dianggap tidak menggunakan sumber daya yang maksimal. Berikut ini merupakan tabel yang berisi data jumlah produksi dan data kerusakan produk UD Lestari bulan April 2017

Tabel 1. Data Produksi UD Lestari Bulan April 2017 (Shift 1)

\begin{tabular}{ccccc}
\hline NO & HARI / TANGGAL & $\begin{array}{c}\text { JUMLAH } \\
\text { PRODUKSI } \\
(\mathrm{Kg})\end{array}$ & $\begin{array}{c}\text { JUMLAH } \\
\text { REJECT } \\
(\mathrm{Kg})\end{array}$ & $\%$ \\
\hline 1 & Senin / 10 April 2017 & 1.560 & 88,5 & $5,6 \%$ \\
2 & Selasa / 11 April 2017 & 1.950 & 94 & $4,8 \%$ \\
3 & Rabu / 12 April 2017 & 1.860 & 68 & $3,6 \%$ \\
4 & Kamis /13 April 2017 & 1.980 & 77,5 & $3,9 \%$ \\
5 & Jum'at /14 April 2017 & 2.070 & 87 & $4,2 \%$ \\
6 & Sabtu/15 April 2017 & 2.070 & 84 & $4 \%$ \\
7 & Senin /17 April 2017 & 2.070 & 45 & $2.7 \%$ \\
8 & Selasa /18 April 2017 & 1.620 & 121 & $7.4 \%$ \\
9 & Rabu /19 April 2017 & 1.620 & 139 & $7.1 \%$ \\
10 & Kamis /20 April 2017 & 1.740 & 115 & $6.6 \%$ \\
\hline
\end{tabular}

Data di atas membuktikan bahwa kerusakan produk biji plastik terjadi setiap hari dan melebihi batas standar yang telah ditetapkan oleh perusahaan UD Lestari. Sesuai dengan permasalahan yang sudah 
dipaparkan di atas maka rumusan masalah dalam penelitian ini adalah apakah faktor-faktor penyebab terjadimya kerusakan produk pada proses produksi biji plastik UD Lestari dan bagaimanakah cara meminimalisir kerusakan produk biji plastic serta tindakan perbaikan seperti apa yang akan dilakukan.

Dalam penelitian ini teori yang digunakan terkait produk atau jasa yang berkualitas adalah keinginan utama konsumen ketika mengkonsumsi suatu produk atau jasa tertentu. Kualitas merupakan suatu kondisi atau karakteristik produk dan / atau jasa yang sesuai dengan keinginan konsumen dan pelanggan (Heizer \& Render, 2015).

Harga yang lebih rendah dan mudah untuk didapatkan menjadikan suatu produk atau jasa berkualitas. Produk atau jasa dapat dikatakan berkualitas apabila produk atau jasa yang dihasilkan oleh suatu perusahaan memiliki harga yang relatif murah dan keberadaan suatu produk tersebut dapat diterima oleh banyak konsumen maupun pelanggan (Tjiptono \& Diana, 1995).

Kualitas sebagai suatu hal yang cocok dan sesuai untuk digunakan memiliki ciri-ciri yaitu produk yang memenuhi permintaan pelanggan dan bebas dari kekurangan.

Pengendalian kualitas adalah suatu tindakan yang dianggap saangat perlu untuk menjamin tercapainya suatu rencana dan tujuan yang telah ditetapkan oleh suatu perusahaan (Juran, 2007). Sedangkan menurut Prawirosentono (2002) pengendalian kualitas adalah kegiatan terstruktur mulai dari pengendalian kualias bahan baku, proses produksi, barang setengah jadi, barang jadi hingga pengiriman produk akhir ke tangan konsumen, untuk itu agar barang atau jasa yang dihasilkan sesuai dengan kualitas yang telah direncanakan maka pengendalian kualitas sangat diperlukan dalam suatu perusahaan.

Berdasarkan pendapat-pendapat para ahli dapat disimpulkan bahwa jika pengendalian kualitas dijalankan dengan baik maka tingkat kerusakan produk dapat diperkecil dan produksi yang dihasilkan sesuai dengan standar. Pengendalian kualitas yang baik dan maksimal akan memberikan keuntungan yang tinggi bagi suatu perusahaan.

Assauri (2004) menjelaskan tujuan pengendalian kualitas adalah sebagai berikut: pertama agar barang hasil produksi dapat mencapai standar kualitas yang telah ditetapkan dan mengusahakan agar biaya inspeksi dapat menjadi serendah mungkin. Kedua mengusahakan agar biaya desain dari produk dan proses dengan menggunakan mutu produksi tertentu dapat menjadi sekecil mungkin. Terakhir mengusahakan agar biaya produksi dapat menjadi semurah mungkin.

Heizer dan Render (2015) menyatakan tujuh alat pengendalian kualitas sebagai berikut: Pertama, check sheet atau lembar periksa adalah sebuah formulir yang dirancang untuk mencatat suatu data tertentu. Kedua, scatter diagram atau diagram pencar yaitu grafik nilai dari suatu karakteristik yang membandingkan dengan nilai karakteristik yang lain dan menunjukkan hubungan antara dua pengukuran. Ketiga, cause and effect diagram adalah alat pengendalian 
kualitas yang menggambarkan secara grafik yaitu menentukan penyebab dari gejala-gejala yang akan mempengaruhi kualitas suatu produk seperti bahan baku, mesin atau peralatan, tenaga kerja dan metode.

Keempat, pareto analysis atau grafik paretoadalah pendekatan yang terkoordinasi untuk mengidentifikasi, mengurutkan dan untuk menyisihkan ketidaksesuaian secara permanen.

Kelima, statistical process control atau pengendalian kualitas statistikyaitu peta ukuran waktu yang menunjukkan nilai-nilai statistik, termasuk garis pusat dan satu atau lebih batas kendali yang didapat secara statistika. Keenam, histogram adalah distribusi yang menunjukkan frekuensi kejadian-kejadian diantara jajaran data yang tinggi dan yang rendah. Terakhir, flow chart atau diagram alur adalah gambar yang menjelaskan langkah-langkah utama, cabang-cabang proses dan produk akhir dari proses produksi barang.

Suatu produk merupakan segala sesuatu yang berwujud dan diciptakan untuk memenuhi kebutuhan hidup manusia. Produk adalah sesuatu yang dapat ditawarkan ke dalam pasar untuk diperhatikan, dimiliki, digunakan atau dikonsumsi sehingga dapat memuaskan keinginan atau kebutuhan konsumen (Kotler \& Keller, 2009). Nasution (2010) mengidentifikasi 8 dimensi kualitas yang dapat digunakan untuk menganalisis karakteristik kualitas produk yaitu adalah sebagai berikut: pertama, performa (performance), berkaitan dengan fungsi suatu produk dan merupakan karakteristik utama yang dipertimbangkan konsumen dalam membeli produk.
Kedua, keistimewaan (features), yaitu performansi yang berguna untuk menambah fungsi dasar.

Ketiga, yakni keandalan (reliability), hal yang berkaitan dengan kemungkinan suatu barang berhasil menjalankan fungsinya. Keempat, yaitu konformansi (conformance), berkaitan dengan tingkat kesesuaian terhadap spesifikasi yang telah ditetapkan. Kelima, daya tahan (durability), yaitu umur ekonomis yang berupa ukuran daya tahan atau masa pakai produk. Keenam, kemampuan pelayanan (serviceability), yaitu kecepatan, kompetensi, kemudahan dan akurasi dalam memberikan layanan untuk perbaikan produk.

Ketujuh, estetika (asthetics), adalah hal yang bersifat subjektif mengenai nilai-nilai estetika atau seni yang berkaitan dengan pertimbangan pribadi. Terakhir, kualitas yang dipersepsikan (perceived quality), konsumen tidak selalu memiliki informasi yang lengkap mengenai atribut-atribut produk, tetapi biasanya konsumen memiliki informasi tentang produk secara tidak langsung.

Ishak (2010) menyatakan bahwa proses produki adalah setiap bagian dari organisasi yang mengambil input dan mengolahnya menjadi output yang diharapkan akan memiliki nilai tambah bagi organisasi dibandingkan dengan input awalnya, sedangkan Ahyari (2002) menyatakan bahwa proses produksi adalah suatu cara, metode ataupun teknik yang digunakan untuk menambah nilai suatu barang dan jasa dengan menggunakan faktor produksi yang ada. Nasution (2010) menjelaskan diagram sebab akibat 
adalah diagram yang terstruktur dan memungkinkan dilakukan suatu analisis lebih terperinci dalam menemukan penyebab-penyebab suatu masalah, ketidaksesuaian dan kesenjangan yang terjadi.

Heizer \& Render (2015) pengertian cause and effect diagram adalah teknis sistematis yang digunakan untuk melihat

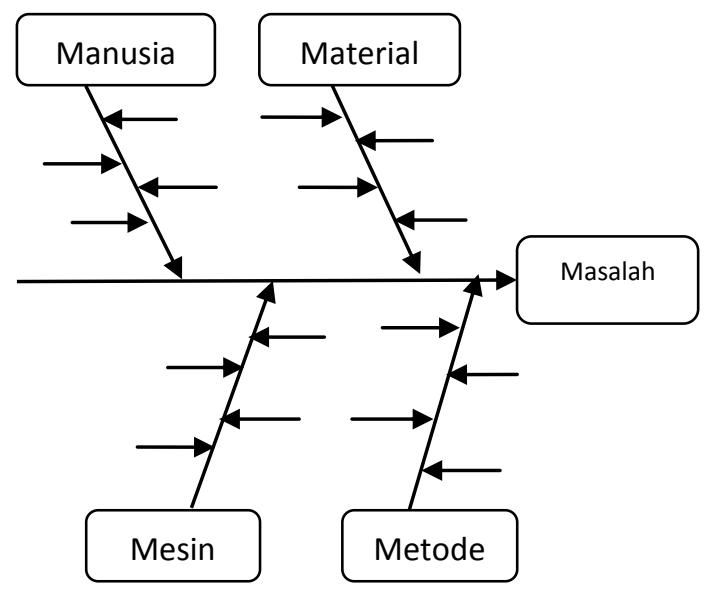

Gambar 1. Diagram Sebab Akibat

Heizer dan Render (2015) menyatakan bahwa diagram pareto adalah pendekatan yang terkoordinasi untuk mengidentifikasi, mengurutkan dan menyisihkan ketidaksesuaian secara permanen. Diagram pareto (Pareto Chart) digunakan untuk menunjukkan jumlah prosentase masing-masing kesalahan atau kerusakan produk yang dapat dijadikan sebagai upaya penyelesaian masalah. kemungkinan tempat masalah kualitas atau alat yang mengidentifikasikan penyebab yang mungkin mempengaruhi hasil. Manfaat diagram ini adalah dapat memisahkan penyebab dari gejala, memfokuskan perhatian pada hal-hal yang relevan, serta dapat diterapkan pada setiap masalah.

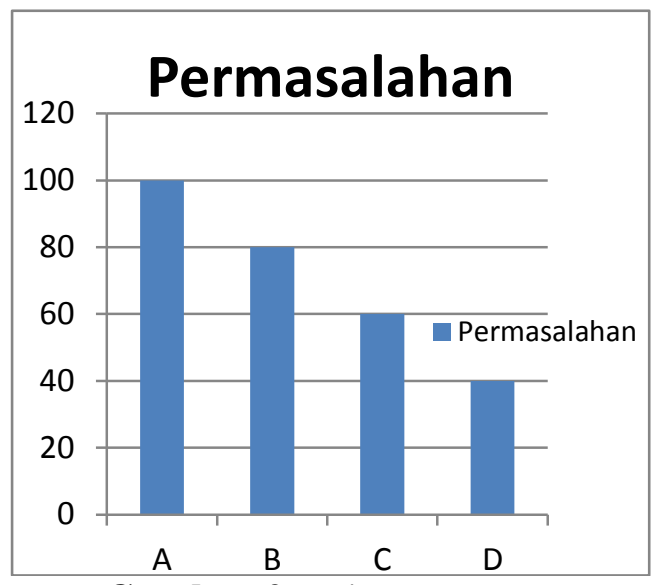

Gambar 2. Diagram Pareto

UD Lestari merupakan perusahaan manufaktur yang bergerak pada bidang pengolahan plastik menjadi biji plastik, dari biji plastik menjadi tali rafia dan tali rafia menjadi tali rumpon. Permasalahan yang dialami oleh UD Lestari adalah kerusakan produk biji plastik yang terjadi setiap harinya. Kerangka pikir penelitian ini disajikan dalam gambar dibawah ini:

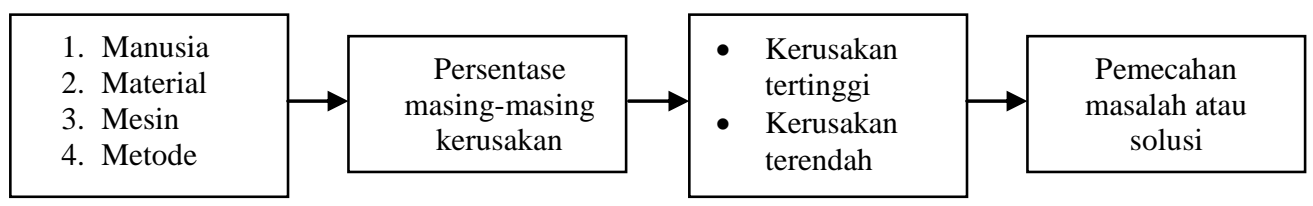

Gambar 3. Kerangka Pikir Penelitian 


\section{METODE PENELITIAN}

Lokasi penelitian ini di UD Lestari yang terletak di Dusun Krajan Gampingan RT 06 RW 01 Desa Gampingan Kecamatan Pagak Kabupaten Malang. Jenis penelitian yang digunakan pada penelitian ini adalah penelitian aplikasi model yaitu penelitian yang menekankan pada pemecahan masalah praktis yang diarahkan untuk menjawab pertanyaan spesifik dalam penentuan kebijakan kinerja tertentu (Indriantoro \& Supomo, 2009).

Pada penelitian ini definisi operasionalnya adalah sebagai berikut: pertama, manusia atau tenaga kerja merupakan orang yang terkait dengan proses produksi pengolahan biji plastik pada perusahaan pengolahan biji plastik UD Lestari dengan indikator kedisiplinan tenaga kerja UD Lestari. Definisi operasional yang kedua adalah material atau bahan bakuyang meliputi bahan baku utama maupun pendukung yang diproses untuk menjadi biji pastik seperti karung plastik dan plastik sablon. Indikator: kualitas bahan baku dan kebersihan bahan baku baik.

Ketiga, mesin merupakan alat atau peralatan yang berhubungan dengan proses pembuatan biji plastik. Indikator: kondisi mesin yang digunakan untuk pengolahan biji plastik pada UD Lestari dan pemeliharaan mesin yang dilakukan oleh UD Lestari. Keempat, metode yaitu merupakan cara yang digunakan oleh tenaga kerja dalam pengolahan biji plastik. Indikator: standar operasional perusahaan pengolahan plastik UD Lestari.

Terakhir, media merupakan tempat dan waktu kerja yang ditetapkan oleh perusahaan pengolahan biji plastik UD Lestari, tetapi faktor media tidak mempengaruhi kualitas produk biji plastik karena lingkungan kerja cukup kondusif dan jam kerja yang sesuai yaitu 8 jam per satu shift.

Sumber data yang digunakan dalam penelitian ini adalah data primer dan sekunder. Data primer adalah data yang diperoleh secara langsung dari sumber data yang diamati dan dicatat untuk pertama kalinya, sedangkan dara sekunder adalah data yang diperoleh secara tidak langsung dan melalui perantara. Teknik pengumpulan data adalah cara yang digunakan peneliti dalam mengumpulkan data.

Teknik pengumpulan data dalam penelitian ini adalah wawancara, observasi dan dokumentasi. Wawancara dilakukan secara langsung kepada pemilik perusahaan, observasi dilakukan oleh peneliti dengan cara turun lapang secara langsung pada obyek yang diteliti, sedangkan dokumentasi adalah mengumpulkan data dari perusahaan oleh peneliti.

Teknik analisis data bertujuan untuk menjelaskan menjelaskan secara urut mengenai penyelesaian permasalahan yang dihadapi oleh perusahaan. Teknik analisis data yang digunakan ada 2 yaitu diagram sebab akibat dan diagram pareto.

Langkah- langkah untuk membuat diagram sebab akibat yaitu mendapatkan kesepakatan tentang masalah yang terjadi dan ungkapan masalah itu sebagai suatu pertanyaan masalah. Dalam penelitian ini permasalahannya adalah kerusakan produk biji plastik UD Lestari. Caranya adalah dengan 
menggambarkan garis horizontal dengan tanda panah pada ujung sebelah kanan dan menuliskan permasalahan yang akan diteliti.

Kedua, menyiapkan data berupa pertanyaan yang akan diajukan dalam memulai penelitian yang didalamnya berperan dalam proses produksi biji plastik di UD Lestari antara lain tenaga kerja, metode, bahan baku, mesin dan lingkungan. Caranya adalah dengan menuliskan penyebab utama dalam kotak yang dihubungkan kearah garis panah utama.

Terakhir adalah menganalisis gambaran tulang ikan dengan pertanyaan mengenai masalah untuk ditempatkan pada sisi kanan dan kategori utama seperti manusia, bahan baku, mesin dan metode ditempatkan pada cabang utama. Selanjutnya langkah-langkah membuat diagram pareto adalah sebagai berikut: menentukan permasalahan atau persoalan yang akan diteliti, menentukan jenis data serta cara mengolah data tersebut, seperti jenis atau macam persoalan, misalnya kerusakan atau kecelakaan, melakukan pengumpulan data yang akan diteliti. Ketiga, membuat ringkasan daftar atau tabel yang mencatat frekuensi terjadinya masalah yang akan diteliti dan dikumpulkan datanya.

Keempat, membuat daftar masalah secara berurutan berdasarkan frekuensi terjadinya suatu masalah mulai dari yang tertinggi sampai ke terendah yaitu diurutkan dari kiri ke kanan serta menghitung frekuensi kumulatif, prosentase dari total kejadian dan prosentase dari total kejadian secara kumulatif. Kelima, melakukan pengumpulan data-data yang diperlukan untuk menganalisis permasalahan.

Keenam menetapkan periode waktu yang akan digunakan untuk menganalisis permasalahan. Ketujuhh, menggambar dua buah garis vertikal dan sebuah garis horizontal. Selanjutnya membuat histogram pada diagram pareto, kemudian memutuskan untuk melakukan tindakan perbaikan terhadap penyebab utama dari masalah yang diteliti. Dan terakhir menunjukkan hasil upaya perbaikan yaitu sesudah dilakukan tindakan korektif berdasarkan prioritas.

\section{HASIL PENELITIAN DAN PEMBAHASAN}

Alat analisis yang digunakan dalam penelitian ini adalah diagram sebab akibat dan diagram pareto. Diagram sebab akibat berfungsi untuk mengidentifikasi faktor-faktor penyebab kerusakan produk. Langkah - langkah dalam membuat diagram sebab akibat adalah menentukan permasalahan yang akan diteliti dan menganalisis faktorfaktor penyebab kerusakan biji plastik.

Faktor-faktor tersebut adalah tenaga kerja, bahan baku, mesin dan metode. Dalam penelitian ini ditemukan 3 jenis kerusakan produk yaitu biji plastik berbentuk beda, biji plastik menempel antara satu dengan yang lainnya dan biji plastik berbentuk bongkahan. Berikut adalah tabel penyebab terjadinya kerusakan produk biji plastik UD Lestari: 
Tabel 2. Faktor Permasalahan Produk Biji Plastik Pada UD Lestari

\begin{tabular}{|c|c|c|c|c|c|}
\hline \multirow[b]{2}{*}{ No } & \multirow[b]{2}{*}{ Primer } & \multirow[b]{2}{*}{ Sekunder } & \multicolumn{3}{|c|}{ Tersier } \\
\hline & & & $\begin{array}{l}\text { Biji Plastik Bentuk } \\
\text { Beda }\end{array}$ & $\begin{array}{l}\text { Biji Plastik } \\
\text { Menempel }\end{array}$ & $\begin{array}{l}\text { Biji Plastik Berbentuk } \\
\text { Bongkahan }\end{array}$ \\
\hline \multirow[t]{3}{*}{1.} & \multirow[t]{3}{*}{$\begin{array}{l}\text { Tenaga } \\
\text { Kerja }\end{array}$} & \multirow[t]{3}{*}{$\begin{array}{c}\text { Kurangnya } \\
\text { kedisiplinan kerja }\end{array}$} & $\begin{array}{c}\text { Tenaga kerja tidak } \\
\text { melakukan } \\
\text { pekerjaan dengan } \\
\text { benar seperti salah } \\
\text { dalam komposisi } \\
\text { pencampuran bahan } \\
\text { baku }\end{array}$ & $\begin{array}{c}\text { Srowol } \\
\text { berjatuhan ke } \\
\text { lantai sehingga } \\
\text { tercampur } \\
\text { dengan kotoran }\end{array}$ & $\begin{array}{l}\text { Kayu yang digunakan } \\
\text { untuk mendorong } \\
\text { bahan baku ke dalam } \\
\text { mesin ikut tergiling } \\
\text { dan bercampur } \\
\text { lelehan plastik }\end{array}$ \\
\hline & & & \multicolumn{3}{|c|}{$\begin{array}{c}\text { Tenaga kerja melakukan kegiatan diluar proses produksi seperti } \\
\text { banyak bicara dan bergurau ketika bekerja }\end{array}$} \\
\hline & & & \multicolumn{3}{|c|}{$\begin{array}{c}\text { Terdapat beberapa tenaga kerja yang tidak masuk kerja sehingga } \\
\text { proses produksi sedikit terganggu }\end{array}$} \\
\hline 2. & Material & $\begin{array}{l}\text { Kualitas dan } \\
\text { tingkat kebersihan } \\
\text { bahan baku }\end{array}$ & \multicolumn{3}{|c|}{$\begin{array}{l}\text { Bahan baku bercampur dengan non plastik (kotoran) } \\
\text { Proses sortir tidak maksimal }\end{array}$} \\
\hline 3. & Mesin & $\begin{array}{l}\text { Mesin sudah tua, } \\
\text { kurang perawatan, } \\
\text { suhu mesin terlalu } \\
\text { panas }\end{array}$ & \multicolumn{3}{|c|}{$\begin{array}{c}\text { Kinerja mesin tidak maksimal } \\
\text { Mesin sering mengalami kerusakan } \\
\text { Setting mesin salah }\end{array}$} \\
\hline 4 & Metode & $\begin{array}{l}\text { Tidak sesuai } \\
\text { prosedur } \\
\text { perusahaan }\end{array}$ & \multicolumn{3}{|c|}{$\begin{array}{l}\text { Mengurangi pekerjaan dengan tidak mengganti air pada kolam } \\
\text { bak dayung sesuai prosedur yang ditentukan perusahaan }\end{array}$} \\
\hline
\end{tabular}

Data diatas didapat dari observasi pada bagian produksi dan melakukan wawancara pada karyawan bagian produksi secara langsung. Berdasarkan faktor-faktor penyebab terjadinya kesalahan dapat dilihat bahwa penyebab terjadinya permasalahan terjadi pada faktor manusia, bahan baku, mesin dan metode. Perbaikan dilakukan terhadap faktor penyebab masalah tersebut, diantaranya adalah manusia (tenaga kerja). Permasalahan pertama pada proses sortir plastik yang masih kurang maksimal yaitu tenaga kerja kurang bersih ketika memisahkan bahan baku berupa plastik dan non plastik seperti besi, tanah, daun, kayu dan lain-lain.

Permasalahan kedua terjadi pada saat proses pencacahan, pencucian dan peleburan plastik menjadi biji plastik yaitu tenaga kerja kurang disiplin (konsentrasi) dalam melakukan pencampuran antara plastik sablon dan karung plastik. Permasalahan selanjutnya tenaga kerja absen sehingga mengganggu proses produksi, tenaga kerja kurang disiplin sehingga mengakibatkan srowol berjatuhan ke lantai dan kotor. Masalah juga terjadi pada saat proses peleburan biji plastik yaitu tenaga kerja kurang fokus dan konsentrasi ketika mengatur suhu panas sehingga biji plastik kurang matang dan terlalu matang.

Material merupakan salah satu penyebab yang ditimbulkan dari kerusakan produk pada perusahaan pengolahan plastik UD Lestari. Bahan baku yang sangat kotor akan mengakibatkan lelehan plastik tidak lolos dari saringan pertama sehingga lelehan plastik akan keluar dari saringan (meluber dari mesin) dan mengakibatkan lelehan berbentuk bongkahan. Ketiga adalah mesin, dikarenakan oleh kondisi mesin yang kurang maksimal. Permasalahan mesin terjadi karena mesin tidak 
kondusif dan kurang perawatan, sehingga mesin sering mengalami kerusakan dan berhenti tiba-tiba ketika proses produksi berjalan. Kemudian permasalahan lainnya terjadi karena mesin berumur tua. Permasalahan terakhir yang disebabkan oleh mesin adalah kesalahan saat mengatur suhu panas pada mesin.

Terakhir adalah metode yaitu proses produksi biji plastik tidak sesuai dengan prosedur terletak pada proses cuci, tenaga kerja tidak mengganti air dalam kolam bak dayung sesuai prosedur. Air kolam hanya diganti sekali dalam satu kali proses produksi sedangkan prosedur yang ditetapkan oleh perusahaan adalah air kolam diganti sebanyak dua kali dalam sekali proses produksi.
Alat analisis yang kedua adalah diagram pareto, diagram pareto berfungsi untuk menentukan prosentase jenis-jenis kerusakan, mengurutkan dari yang terbesar ke yang terkecil dan meminimalisir kerusakan dengan cara menghilangkan penyebab kerusakan yang paling banyak terjadi. Langkahlangkah menentukan diagram pareto adalah mengumpulkan data kerusakan produk biji plastik, membuat daftar kerusakan produk dengan mengurutkan berdasarkan jenis kerusakan yang paling banyak terjadi kemudian menentukan penyebab kerusakan yang akan dihilangkan terlebih dahulu. Hasil yang didapat dari digram pareto menunjukkan bahwa kerusakan biji plastik berbentuk bongkahan adalah kerusakan dengan jumlah terbanyak

Tabel 3. Hasil Produk Biji Plastik Selama 3 Bulan

\begin{tabular}{cccccc}
\hline \multirow{2}{*}{ No } & \multirow{2}{*}{ Jenis Kerusakan } & \multicolumn{3}{c}{ Jumlah Kerusakan $(\mathrm{Kg})$} & \multirow{2}{*}{ Total } \\
\cline { 3 - 5 } & & Februari & Maret & April & \\
\hline 1 & Bentuk bongkahan & 2.100 & 2.338 & 2.619 & 7.057 \\
2 & Bentuk Beda & 1.324 & 1.305 & 1.529 & 4.176 \\
3 & Menempel satu dengan yang & 633 & 595 & 885 & 2.113 \\
& lainnya & 4.075 & 4.238 & 5.033 & 13.346 \\
\hline
\end{tabular}

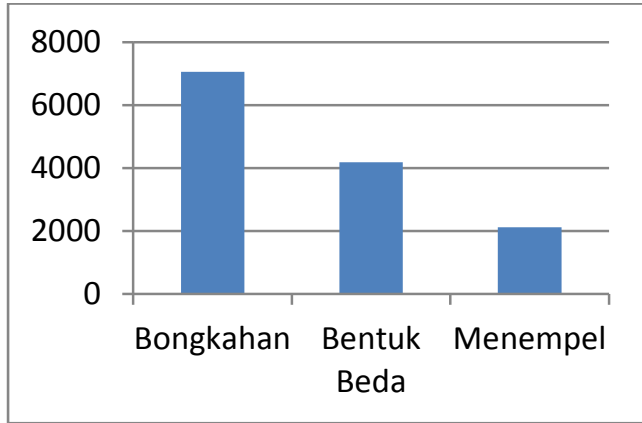

Gambar 4. Diagram Pareto Kerusakan Produk Selama 3 Bulan

Berdasarkan Gambar 4. dapat diketahui bahwa kerusakan biji plastik yang berbentuk bongkahan merupakan kerusakan yang paling banyak terjadi pada UD Lestari selama 3 bulan, selanjutnya kerusakan yang berbentuk beda dan yang paling sedikit adalah jenis kerusakan menempel antara satu dengan yang lainnya.

\section{SIMPULAN}

Berdasarkan hasil penelitian, ditemukan adanya kecacatan atau kerusakan produk pada setiap produksi biji plastik pada perusahaan pengolahan plastik UD Lestari. Kecacatan atau kerusakan produk 
terjadi hampir setiap hari pada setiap proses produksinya. Kerusakan produk yang terjadi melebihi standar kerusakan yang telah ditetapkan oleh perusahaan yaitu $2,5 \%$ dari produk akhir pada setiap 1 shift produksi. Tetapi hasil yang ditemukan kerusakan yang sering terjadi adalah melebihi $2,5 \%$ pada setiap shiftnya. Terdapat 3 jenis kerusakan yang terjadi yaitu biji plastik berbentuk beda, biji plastik menempel antara satu dengan yang lainnya dan biji plastik berbentuk bongkahan. Terdapat 4 faktor yang menyebabkan terjadinya kerusakan tersebut yaitu faktor manusia, material, mesin dan metode.

\section{DAFTAR PUSTAKA}

Ahyari, Agus. 2002. Manajemen Produksi: Pengendalian Produks, Edisi Keempat, Buku Dua. Yogyakarta: Badan Penerbit Fakultas Ekonomi

Assauri, Sofjan. 2004. Manajemen Produksi dan Operasi, Edisi Revisi. Jakarta: Lembaga Penerbit Fakultas Ekonomi Universitas Indonesia.

Heizer, Jay dan Berry Render. 2015. Manajemen Operasi: Manajemen Keberlangsungan dan Rantai
Pasokan Buku 1 Edisi 11. Jakarta:Salemba Empat Indriantoro, Nur dan Bambang Supomo. 2009. Metodologi Penelitian Bisnis Untuk Akuntansi dan Manajemen. Yogyakarta: BPFE.

Ishak, Aulia. 2010. Manajemen Operasi. Yogyakarta: Graha Ilmu.

Juran, Josep dan Suyadi Prawirosentono. 2007.

Filosofi Baru Tentang Manajemen Mutu

Terpadu Abad 21 "Kiat Membangun Bisnis Kompetitif”. Jakarta. Bumi Aksara.

Kotler, Philip \& Kevin Lane Keller. 2009. Manajemen Pemasaran, Edisi 13 Jilid 2. Jakarta; Erlangga.

Nasution, M.N. 2010. Manajemen Mutu Terpadu Edisi Kedua. Bogor: Ghalia Indonesia.

Prawirosentono, Suyadi. 2002. Manajemen Mutu Terpadu Cetakan Pertama. Jakarta: Bumi Aksara.

Tjiptono, Fandy dan Anastasia Diana. 1995. Total Quality Management Edisi Revisi. Yogyakarta: Andi Offset.

Tjiptono, Fandy dan Anastasia Diana. 2005. Total Quality Management Edisi Revisi. Yogyakarta: Andi Offset. 